\title{
THE COGITATION OF THE VALUE OF EPISTEMIC DIVERSITY IN SOUTH AFRICAN JURISPRUDENCE, AS INFLUENCED BY THE PROJECT OF INTELLECTUAL HISTORY: LESSONS FROM RHODES MUST FALL - “ALL “RHODES" LEAD TO THE COLONISATION OF THE MIND'
}

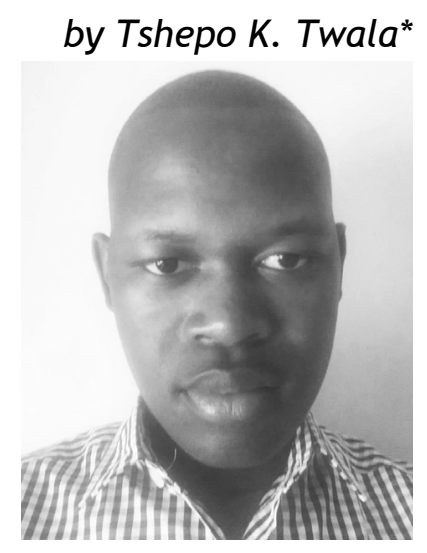

* Third year LLB student, University of Pretoria. I dedicate all my writings to my late mother, Gugile Isabella Twala (1965-2002). This article examines the ideal epistemic aims of a critical jurisprudence in South Africa. It explains that epistemology is concerned with giving an account of knowledge and suggests that if legal scholars ought to aim at having their students acquire knowledge then their epistemic aims should be related to this goal. I contend that the epistemic aims of the law do not necessarily concern curricular subjects but with the way the work of a legal scholar should be guided by an understanding of the nature of knowledge itself. This paper not only deals with the historical development of political traditions but also gives attention to religious and communal intellectual practices. This paper also mulls the development of a South African critical race theory with reference to the thought of Steve Biko. In a wide sense, the purpose of this paper is also to bring the insights of the Black Radical Tradition to bear on the study of law and jurisprudence, with attention placed on the predicament of 'post'-apartheid South Africa. In essence, this paper demonstrates that: 'Only by rethinking the ideas that made us can we re-imagine the world'. My thanks to Professor Karin van Marle for explicate comments and perspicacious discussions. I must also thank Nikeliwe Vilakazi, Nikithemba Monakali, Adv Mayuri Pillay, Mduduzi Twala, Muzi Mgabhi, Siphiwe Nkwanyana and Kagiso Mathebula for inputs, support and editorial suggestions to the final draft of this article. Lastly, I thank Dr Joel Modiri and Dr Tshepo Madlingozi for the inspiration towards the journey of legal writing. 


\section{Introduction}

The project of intellectual history is to reconsider the traditions and ideas and unearth suppressed knowledges that shaped (and are shaping) South Africa. ${ }^{1}$ Critical Jurisprudence offers an ethics of law against an aesthetics of existence and the nihilism of power for the melancholic lawyer. ${ }^{2}$ Douzinas and Gearey describe the history of jurisprudence 'as the movement from general to restricted concerns, where thinking about the law of the law' was substituted and overhauled by 'a professional and technical approach'. ${ }^{3}$ This essay reflects on how critical legal theories (i.e. legal pluralism, Black Consciousness (BC), feminist legal theory, Marxism, power and Critical Race Theory (CRT)) could offer critical interventions in the development of a critical jurisprudence and the fundamental paradox of 'post'-apartheid South Africa, namely the escalation and continuation of racial inequalities and social hierarchies produced through over 350 years of white colonial domination in a 'new' constitutional order that embraces egalitarian and non-racial ideals. ${ }^{4}$ This will be done through an investigation of the above-mentioned theories in relation to the evolution of intellectual traditions in South Africa and how they perpetuate(d) epistemicide. The calls for a 'race conscious' and general jurisprudence shall be advanced through the epistemological paradigm of BC, CRT, Critical Race Feminism (CRF) and classism which offers a political account of the law through the acknowledgment of the centrality of race in law. ${ }^{5}$ I also reflect on the Rhodes Must Fall Movement (RMFM) and how it purported to advance the development of a feminist jurisprudence, eradication of intellectual eclipse and class and the need to build the power of the poor from below. ${ }^{6}$

1 K Van Marle 'The complicity of language, knowledge and justice' (2017) 49(1) Acta Academia 107.

2 C Douzinas and A Gearey Critical jurisprudence: The political philosophy of Justice (2005) 3-5.

3 J Modiri 'The crises in legal education' (2014) 46(3) Acta Academia 3.

4 JM Modiri "The jurisprudence of Steve Biko: A study in race, law and power in the "afterlife" of colonial-apartheid' (2017) unpublished PhD thesis, University of Pretoria 1.

5 N Nhleko 'Positioning race at the centre of legal discourse in post-apartheid South Africa: Dissecting Cliff v Electronic Media (Pty) Ltd and the land reform crisis' (2016) 10 Pretoria University Law Press 112.

6 S Zikode, 2 December 2011, 'Poor people's movements and the Law', http:// abahlali.org/node/8551 (accessed 26 May 2018). 


\section{The project of intellectual history: The shift Towards a critical jurisprudence, intellectual activism and the possibilities for epistemic diversity and epistemic justice}

What's her name? Charnell? She is a kitchen assistant in Observatory and now she's an expert. She doesn't know what the budget of the City Council is; she doesn't know what money they get. She doesn't know this stuff. She is a kitchen assistant. ${ }^{7}$

The quote above refers to the - racial, sexist and classist - comment made by Judge Leslie Weinkove during an eviction case in Cape Town. This quote reflects that the views of the marginalised as well as the dominant are distorted by relationships of domination and oppression. ${ }^{8}$ In accordance with the notion of 'listening to the spirit from (un)expected places' by De Beer, ${ }^{9}$ the themes discussed below demonstrate the epistemic value of diversity and the need for intellectual activism in the advocacy of a critical jurisprudence. Vale argues that '[p]eople who understand everything get no stories' 10 He uses this quote to demonstrate the importance of rejecting a past and present that insists on the grand narrative as it denies the multiplicity of voices and stories. ${ }^{11}$

\subsection{Black Consciousness (BC): A study of the jurisprudence of Steve Biko}

Steve Biko echoes the calls for race consciousness through the ideology of BC which centres upon the idea that the mental emancipation of the Black man is essential to the realisation of de facto liberation. ${ }^{12}$ One cannot understand the intellectual or political ideas of $\mathrm{BC}$ in isolation without taking into account the philosophical,

7 News24, 31 January 2017 'Bromwell Street judge stuns with court comments', https://www.news24.com/SouthAfrica/News/bromwell-street-judge-stuns-withcourt-comments-20170131 (accessed 20 May 2018).

8 S Freire Pedagogy of the oppressed (2000) 31-35.

9 SF De Beer 'Urban social movements in South Africa today: Its meaning for theological education and the church' (2017) 73(3) Aosis 2.

$10 \mathrm{P}$ Vale (2014) 'Of ships, bedraggled crews and the miscegenation of ideas. Interpreting intellectual traditions in South Africa' in P Vale; L Hamilton and $\mathrm{EH}$ Prinsloo (eds) Intellectual traditions in South Africa. Ideas, individuals and institutions 1.

11 As above.

12 S Biko I write what I like (1987) 29. In Biko's writings, we find what could be called a 'materialist' or 'realist' account of social identity - in contrast to a discursive or idealist account. Most fully elaborated in the work of Linda Martin Alcoff, a materialist or realist conception of identity proceeds from the belief that the social identities of humans have 'constitutive power' and are 'epistemically salient and ontologically real'. 
social and political milieu from which they originated. ${ }^{13} \mathrm{BC}$ is both a philosophy and a movement that demands the black person's coming into consciousness of herself as black. ${ }^{14} \mathrm{BC}$ suggests that there should be a realisation that racism is not a mistake but an intentional act and a strong solidarity among blacks as the victims of white racism. ${ }^{15}$ According to Biko, BC is the realisation, by the black man with his brothers, of the need to rally together around the cause of their oppression and to operate as a group in order to rid themselves of the shackles that bind them to perpetual servitude. ${ }^{16}$ Biko portrays that, while the injustice of excluding members of marginalised groups from knowledge production and dissemination has been widely accepted, the epistemic relevance and role of marginality and greater inclusiveness in creating more justified knowledge claims are imperative in the advocacy of intellectual activism and stimulation of epistemic diversity. ${ }^{17}$

Echoing Biko, I contest for the embrace of a race conscious jurisprudence that inspires a culture that is antagonistic towards institutions that perpetuate racist ideology. ${ }^{18} \mathrm{BC}$ is not a movement to 'enter' the white South African polity but to (re)create it and 'establish a completely new system'. ${ }^{19}$ In accordance with the dictates of the African existential philosophy, black existential philosophy is a systematic existential-phenomenological approach to the lived experience of black people in an intrinsically anti-black space(s). ${ }^{20}$ In such spaces, anti-black racism plays a supreme role in the lived experiences of blacks. Douzinas and Gearey formulate CRT as an approach to law, society, politics and discourse that repeatedly stages a confrontation between 'Black power' and 'white law'. ${ }^{21}$ The shift from a general jurisprudence to a restricted jurisprudence is described as a story of decline because it has resulted in the cognitive and moral impoverishment of legal theory. ${ }^{22}$ To comprehend how anti-black spaces were created and maintained, CRT relies on the historical analysis, social science insights and multidisciplinary

13 MP More 'The intellectual foundations of the Black Consciousness Movement' in P Vale; L Hamilton and EH Prinsloo (eds) Intellectual traditions in South Africa. Ideas, individuals and institutions (2014) 173.

14 More (n 13) 177.

15 S Biko 'Black Consciousness and the quest for a true humanity' in PH Coetzee \& APJ Roux (eds) The African Philosophy Reader (2003) 79.

16 Biko (n 15) 53.

17 E Robertson 'The epistemic value of diversity' (2013) 47(2) Journal of Philosophy of Education 299. The principles of black consciousness should be employed by black people so as to empower black people to remove themselves from the position that they have been placed in through centuries of oppression.

18 Nhleko (n 5) 123.

19 GM Gerhart Black Power in South Africa: The evolution of an ideology (1978) 276.

20 More (n 13) 179-181.

21 Douzinas (n 2) 259.

22 Douzinas (n 2 ) 4. 
thinking for the general jurisprudence to gain this understanding. ${ }^{23}$ Such reliance perpetuates the confrontation of the 'hermeneutical injustice' - a form of epistemic injustice that leaves its victims without a conceptual framework for articulating their experiences either to themselves or to others as a result of the forced implantation of colonial epistemology in the black society. ${ }^{24}$ South Africa, Biko suggests, will not return to itself and to the African people to whom it belongs if the concept of reality, knowledge and reason imposed by the white settler-colonialist was not dislodged from epistemic legitimacy and authority. ${ }^{25}$ Thus, it is fair to say that the resurgence of Biko's call for racial consciousness is accounted for by the paucity of intellectual thought in the prevailing social and political climate in South Africa.

Biko critiqued Christianity, arguing that it was largely irrelevant in its present form to young people: too passive in its dealing with oppression, too accepting of the status quo and too bureaucratic. ${ }^{26}$ According to him, the rise and influence of black theology in the Black Consciousness Movement (BCM) represents the need for individuals to foster a sense of pride and the capacity to question authority - in other words, the biblical interpretations and messages, especially Christianity, had to be re-interpreted and redefined and rather preach that it is a sin to allow oneself to be oppressed. ${ }^{27}$ He claimed that $\mathrm{BC}$ had to be connected to black theology so that religion would not become an obstacle to liberation. ${ }^{28}$ Judge Weinkove's comment towards Charnell represents the perpetual role of marginality in South Africa, 'post'-apartheid, and its exclusion of voices from unexpected places because of being black. The manifestation of his comment is two-fold: (i) those, such as Charnell - a black woman, that are thought of as 'unexpected places' is because their spaces are poor, disenfranchised, delegitimised and seen as unable to think for themselves, to hold wisdom that could contribute to the greater good or to be clear and incisive ${ }^{29}$ and (ii) there is a dire need to challenge the dominant framing of 'post'-apartheid law with alternative theorisations of race, power and law - thereby widening the intellectual space that can be made audible to the present moment. ${ }^{30}$ Judge Weinkove's remark(s) reinforces Biko's notion that race is a

23 J Modiri 'The colour of law, power and knowledge' (2012) 28 South African Journal on Human Rights 420.

24 Robertson (n 17) 302.

25 Modiri (n 4) 188.

26 A Egan 'Christianity as an intellectual tradition in South Africa: Les Trahisons des clercs' in P Vale; L Hamilton and EH Prinsloo (eds) Intellectual traditions in South Africa. Ideas, individuals and institutions (2014) 262.

27 C Esterhuizen 'South African Social Theory: steve biko' unpublished msocsci thesis, university of cape town, 2015 36-37.

28 Egan (n 26) 251.

29 De Beer (n 9) 1.

30 Modiri (n 4) 234. 
proxy for power and privilege in the South African society and demonstrates why it is necessary for the African society to view acceptance of oppression as a sin so as to challenge this proxy. ${ }^{31} \mathrm{His}$ comment towards Charnell demonstrates how racism was used as a tool to uphold epistemic violence towards blacks in apartheid as they, blacks, especially woman, were considered as lacking the intellect to introduce certain ideas in order to develop a tradition of valuing epistemic diversity.

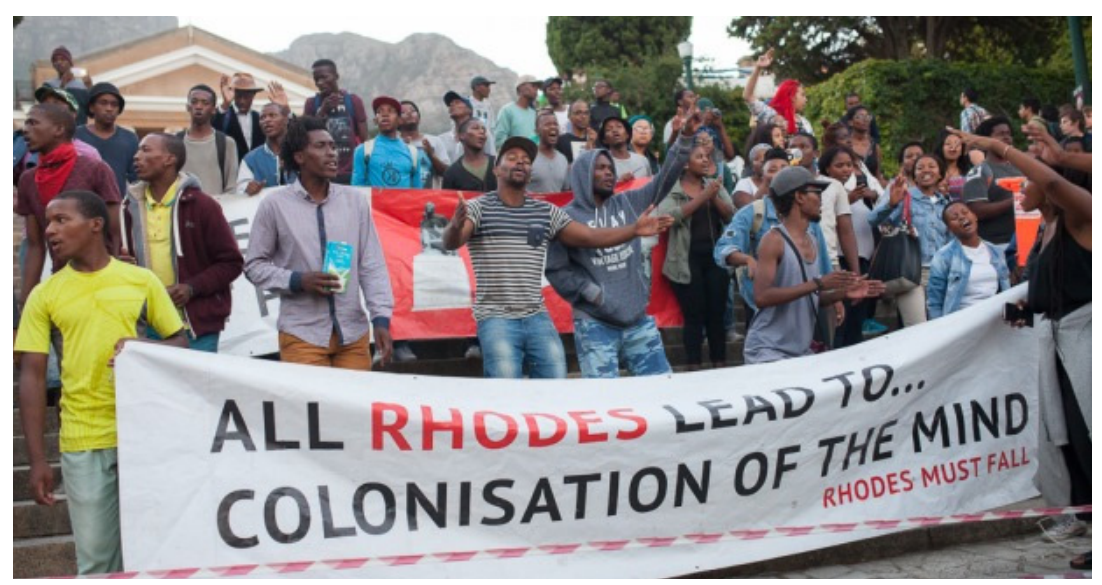

Figure 1: photograph by Ashraf Hendricks ${ }^{32}$

This picture was captured in 2015 during the 'Rhodes Must Fall Movement' (RMFM), where students demanded that education must be free from Western epistemological domination, epistemic violence, Eurocentrism and worldviews that were designed to exploit, subjugate and degrade Africans and other formerly colonised peoples. ${ }^{33}$ The notion 'all Rhodes lead to ... colonisation mind' illustrates the students' critical introspection and declaration of their rejection of the oppression and exfoliation that the legacy of Rhodes

31 Esterhuizen (n 27) 36. The comments made by Judge Weinkove during this matter are in direct conflict with the Constitution and could easily lead to an erosion in confidence in the judicial system.

32 In this photo, Ashraf Hendricks demonstrates epistemic value of diversity and the need for intellectual spaces where 'fallism' feeds off the attempted epistemicide of African thought such as decoloniality and Afrocentricity and decoloniality.

33 International $360^{\circ}, 13$ November 2016 'Decolonisation of higher education: Dismantling epistemic violence and Eurocentrism in South Africa', https:// libya360.wordpress.com/2016/11/13/decolonisation-of-higher-education-dis mantling-epistemic-violence-and-eurocentrism-in-south-africa/ (accessed 22 May 2018). 
in many ways embodies. ${ }^{34}$ Students called for the end of domination by 'white, male, heterosexual, Western capitalist, European world views' in higher education and incorporation of other South African, African and global 'perspectives, experiences and epistemologies' as the central tenets of the curriculum, teaching, learning and research in South Africa. ${ }^{35}$ The RMFM was a collective mobilisation by staff, students and workers at the University of Cape Town (UCT) against institutional racism practised at the institution. ${ }^{36}$ The Students stressed that; although policies might be there, the willingness to implement them is lacking - thus, the higher education system 'remains a colonial outpost' up to this day, reproducing hegemonic identities instead of eliminating hegemony. ${ }^{37}$ The reproduction of Eurocentric epistemic hegemonies in the South African education system is signified by the fact that most South African academics who teach about Africa rely primarily on Western interpretations of the continent. ${ }^{38}$ The students' demands/arguments epitomise Biko's call for the development of an antagonistic attitude towards institutions that perpetuate racist ideology in order to dismantle the reproduction of Eurocentric epistemic hegemonies that have dominated South Africa because if, for example, the higher education is not free from Western epistemological hegemony as its central tenet and unwillingness to implement a curriculum that invigorates South African and African epistemologies, the culture of producing students that are racially nonconscious will endure. The project of deracialising/decolonising the higher education system by the RMFM activists is about the consciousness and rejection of norms, customs, values and worldviews imposed by the [former] colonisers to accelerate the call for reclaiming the indigenous knowledge systems of Africa in the higher education system. ${ }^{39}$ However, it is imperative to take into cognisance that the purported decolonisation of the curriculum will not neglect other knowledge systems and the global context - institutions still have to develop graduates knowledgeable about the world and all its complexity, however, the education must

34 See City of Tshwane Metropolitan Municipality $v$ Afriforum and Another 2016 (6) SA 279 (CC) para 165 for a similar illustration by the judiciary on colonial symbolism.

35 International $360^{\circ}$ (n 33).

36 P Du Preez 'Critical transformation in higher education: Ethical reflections on \#MustFall movements and concomitant gender-based violence' (2017) 31(6) South African Journal of Higher Education 99.

37 As above. This position has been exhibited by the Department of Basic Education of the Eurocentric History curriculum that has continuously defended the colonial propaganda and its proposed for the establishment of an Afrocentric History curriculum.

38 As above.

39 As above. 
be free from Western epistemological domination that has continuously defended colonial-apartheid propaganda. ${ }^{40}$

\subsection{Feminist jurisprudence: A movement to end sexism, sexist oppression and exploitation}

'Feminism demands the enlarged mentality that allows the imagination to run free'. 41

In this essay, contrary to Smart's warning against the quest for a feminist jurisprudence, ${ }^{42}$ I exclaim for a feminist jurisprudence that approaches questions concerning women and the law in more dynamic ways by engaging with all cultural forms and spaces that influence women's subjective experience in terms of how they are perceived, portrayed and ultimately, treated. ${ }^{43}$ Such a jurisprudence could seek ways in which to investigates implicit reinscriptions and invocations of gender injustice and identify the gender implications of laws that claim to be neutral. ${ }^{44}$ The substantial endowment of feminist jurisprudence to legal theory includes: (i) the construction of the female subject in the language of law; (ii) explicit feminist questions involving the exclusion of women from certain areas of law; (iii) speculations of manners through which legal space be transformed to better reflect women's interests and experience. In other words, feminism signifies an intellectual and political movement that investigates patriarchal social structures and agitates for women to be treated as full human beings deserving of equal rights. ${ }^{45}$ It should be noted that I am not saying males are not capable of being custodians of feminist jurisprudence but I demonstrate the need for the total transformation of thinking from the parasite of whiteness to transform the world to be free of patriarchy, antiblackness, self-hating white systems in various research and study fields in order to demonstrate why it is intellectual obscuring to entrench their dominance, that fails to combat/eradicate imperative

40 International $360^{\circ}$ (n 33). The current Eurocentric curriculum, coupled with epistemic violence, does not contribute to a much-needed reimagining of the past and shaping of the present and future on the African continent. This can only be achieved through a curriculum that 'reconstructs' Africa from the civilisational, historical, political standpoint and political economy perspectives. However, this will not happen until the Eurocentric institutional cultures and staff demographics at universities fundamentally change.

41 D Cornell Just cause: Freedom, identity, and rights (2000) 7.

42 K van Marle "“We exist, but who are we?" Feminism and the power of sociological Law' (2012) 20(2) Feminist Legal Studies 156.

43 J Modiri 'Popular culture, law and our "sexed and gendered lives": Feminist reflections on "refusal" and "sisterhood" (2012) 23 Stell LR 132.

44 As above.

$45 \mathrm{H}$ Moffet 'Feminism and the South African polity' in P Vale; L Hamilton and EH Prinsloo (eds) Intellectual traditions in South Africa. Ideas, individuals and institutions (2014) 225. 
issues such as gender oppression, in academia. ${ }^{46}$ Mere entrenchment of women's rights does not liberate them from the impotent intellectual spaces they find themselves in - rather, what is needed is a commitment, through legal pluralism and other critical legal theories, towards the development of feminist jurisprudence in the society. ${ }^{47}$

Accordingly, during RMFM, students called for the institutional change at universities which must include 'demasculanising and degendering' the institutions. In other words, by continuously endorsing male-dominated academia that fails to address gender oppression in their research and respective fields of study, the patriarchal norms will continue to devalue the importance of epistemic diversity as it leads to the continuous gender-based intellectual 'obscuring' and reproduction of students who are not gender-sensitive/gender nonconscious - thus returning to a restricted jurisprudence. This demonstrates why the shift from a general jurisprudence to a restricted jurisprudence is narrated as a story of decline because it has resulted in the cognitive and moral impoverishment of legal theory. ${ }^{48}$ This impoverishment is signified by the lack of the advocacy of a feminist jurisprudence in most fields of legal academia in order to facilitate a return to a general jurisprudence because no effective transformation will occur if legal theory is cognitively and morally impoverished. ${ }^{49}$ In other words, various research and study fields should strive to educate students that the mere fact that human bodies are designed to perform certain procreative functions, biological elements need not dictate intellectual function of woman. In this way, the reproduction of students who are gender nonconscious can be eliminated and degendering or demasculanising of institutions can be achieved as they will be able to contest for a female-inclusive jurisprudential dispensation.

bell hooks explains feminism in her book as 'a movement to end sexism, sexist exploitation and oppression'. ${ }^{50}$ Feminism demands a non-essentialist theory of human sexuality and desire to achieve an understanding of the power relations between the sexes. ${ }^{51} \mathrm{~A}$

46 See A Nyamnjoh 'The phenomenology of Rhodes Must Fall: Student activism and the experience of alienation at the University of Cape Town' (2017) 39(1) Strategic Review for Southern Africa 256.

47 See Bhe and Others $v$ Khayelitsha Magistrate and Others 2005 (1) BCLR 1 (CC) where the court progressively demonstrated the importance of having a femaleinclusive jurisprudence.

48 Douzinas (n 2) 4.

49 K Klare 'Legal culture and transformative constitutionalism' (1998) 14 South African Journal on Human Rights 177-180.

50 N Goba 'Queer women of colour: The intersection of culture and identity' (2016) 10 Pretoria University Law Press 52.

51 T Moi The feminist reader: Essays on gender and the politics of literary criticism (1989) 117. 
discipline which focuses on intersectionality and non-essentialism, CRF, was born out of the feeling that feminist jurisprudence did not thoroughly acknowledge the racial element of sexism and gender oppression and that CRT did not intimately address feminist concerns and gender issues. ${ }^{52}$ CRF acknowledges the racial element of gender oppression, which is very relevant in South Africa where black women not only experience epistemic violence/oppression for being female, but also for being black; therefore to simply categorise their experience on the basis of sex would not be staying true to the actual oppression they experience. ${ }^{53}$ Thus, the challenge of achieving equality within this transformation project involves the eradication of systemic forms of discrimination and material disadvantage based on race, gender and other forms of inequality towards women. ${ }^{54}$ From a Christianity perspective, although feminism was regarded as 'divisive' by many struggle leaders in the 1970s and 1980s (including Biko), feminist theologians contended that if theology (i.e. Christianity) was a discourse for freedom of oppression, it had to address gender oppression, particularly since the Constitution declared it unconstitutional. ${ }^{55}$ This means that 'post'-colonial biblical studies would have to focus on the inequalities and complexities of the postcolonial (and post-apartheid) society in which they find themselves in. 56

Feminist jurisprudence at present, it would appear, needs larger audiences and more participants, more listeners and more sections to discuss and debate. ${ }^{57}$ This can primarily be done through an engagement with a general jurisprudence within the academy. ${ }^{58}$ This assertion does not necessarily mean that such a dialogue should be strictly done through terms dictated by traditional general jurisprudence; if so, this engagement would not only be futile but could be possibly counterproductive. ${ }^{59}$ This engagement would, however, mean posing questions which are deemed general and universal such as what an ideal feminist jurisprudence would entail and come up with general articulations relevant to feminisms as well as other related concerns of marginality and intersectionality; as such, the methodology and concerns of a general jurisprudence would also widen. ${ }^{60}$

52 Modiri (n 23) 418.

53 Goba (n 50) 45.

54 Klare (n 49) 185.

55 Egan (n 26) 262.

56 Egan (n 26) 263.

57 N Thayyil 'Feminist jurisprudence and navel grazings' (2008) UCL Jurisprudence Review 324. A feminist jurisprudence that engages with normative ideas of justice, tempered by social differentiation, is necessary. 58 D Plunkett and S Shapiro 'Law, morality, and everything else: General Douzinas (n 2) 3-8.

60 As above. 


\subsection{Marxism: The connection between material production and the control of intellectual production and the democratisation of access to knowledge}

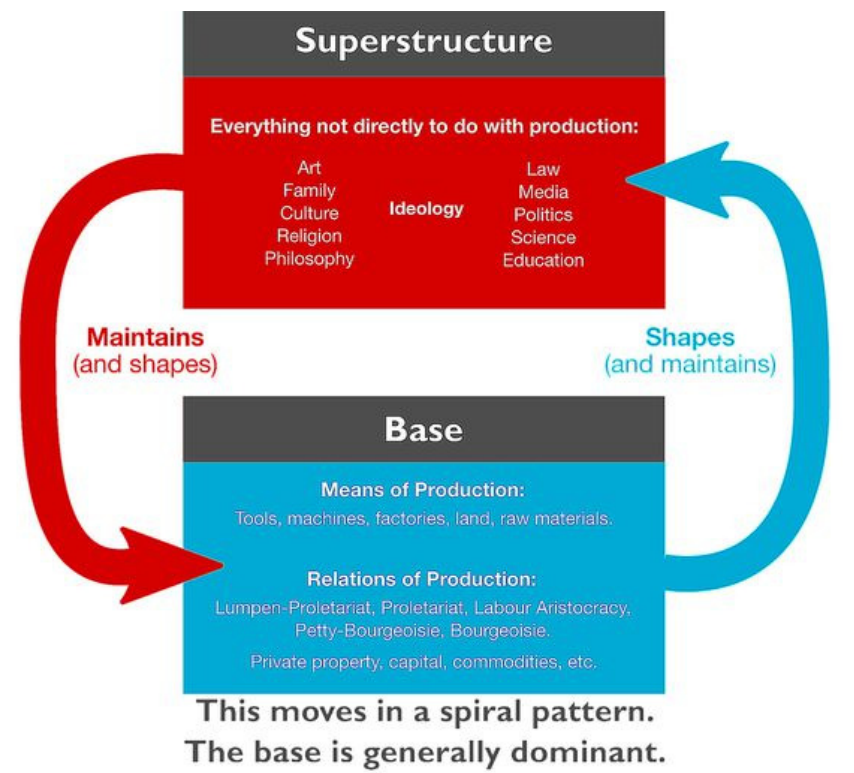

Figure 2: diagram by The Narratologist ${ }^{61}$

Defenders of the epistemic value of diversity maintain that what passes for 'knowledge' in many fields is not in fact universally valid but rather represents the interests and perspectives of the typical knowledge producers. ${ }^{62}$ Marxism is a system of sociology, a philosophy of man and society and a political doctrine - it is a method of socioeconomic analysis that views social conflict and class relations using a materialist interpretation of historical development and takes a contentious perspective of social transformation. ${ }^{63}$ Marxism, as a critical theory, emphasises and tries to expose the law's ideological

61 In this diagram, The Narratologist focuses on the theoretical concepts of the 'base' and 'superstructure' developed by Karl Marx (hereafter, Marx).

62 Robertson (n 17) 299.

63 T Tsikata 'The Marxist Theory of law and its critique of idealist legal theory' (1977) 14 University of Ghana Law Journal 165-170. 
effects. ${ }^{64}$ The central focus of Marxist law is on the development of the form of law that emerges in the capitalist mode of production. ${ }^{65}$ Thus, for Marxism, the presentation of socialism does not tum principally on distribution but on production. ${ }^{66}$ Marx used the metaphor of the 'base' and 'superstructure' to describe the social structure (as illustrated in figure 2 above), which he refers to as the totality of social relations by which humans produce and re-produce their social existence. ${ }^{67}$ The mode of production forms the base of every society, determining its shape and institutions, while the organisation of our economic activity is located amongst the institutions of the superstructure - thus, these institutions determine the type of legal, political and cultural institutions we have. ${ }^{68}$

The dominion of the economy as determining the shape and function of all institutions in society has led some Marxists to underrate the significance of law in the working of capitalism. ${ }^{69}$ Foucault presents the notion of governmentality as a specific and complex form of power which has its target population, as its principal form of knowledge political economy and its essential technical means apparatus of security. ${ }^{70} \mathrm{He}$ argues that notion of governmentality addresses both the practices by which modern governments exercise control over their populations (it encompasses practical and ideational components), and the rationalities by which these practices appear 'normal'. ${ }^{71}$ An analysis of governmentality opens up the possibilities of tracing not only policies and practices, but also actors and their subject positions in the discourses that form them. ${ }^{72}$ In RMFM, the students contested for the revisiting and revision of the Freedom Charter with a special focus on realising free education through the total destruction of economic and political legacies of colonial domination. ${ }^{73}$ However, this contestation resulted in rubber bullets and stun grenades fired on UCT student protesters and this is where we see how governmentality is practiced in order to control the population thereby intellectually 'obscuring' them from addressing their concerns over the policies and practices of the

S Veitch et al Jurisprudence: themes and concepts (2012) 230. See A Nash More 'The double lives of South African Marxism' in P Vale; L Hamilton and EH Prinsloo (eds) Intellectual traditions in South Africa. Ideas, individuals and institutions (2014) 55.

65 EB Pashukanis The general theory of law \& Marxism (2003) xi.

66 Pashukanis (n 65) 19.

67 Veitch (n 64) 227.

68 As above.

69 B Smart Foucault, Marxism and critique (2010) 32-52.

70 Veitch (n 64) 240.

71 P Christie "Changing regimes: Governmentality and education policy in postapartheid South Africa' (2006) 26(4) International Journal of Educational Development 374.

72 Christie (n 71) 378.

73 The DailyVox, 30 September 2016 'Revisiting The ABCs Of The Decolonial Paradigm Of Fallism', https://www.thedailyvox.co.za/wandile-ngcawenirevisiting-abcs-decolonial-paradigm-fallism/ (accessed 25 May 2018). 
government that deny them, the marginalised, the opportunity to participate in the economic development and policy of the country. In other words, the marginalised, forming the base, are deemed to be too poor to determine the type of governmental, legal, political and cultural institutions we have - thus, frustrating the democratisation of knowledge. Marx observes that "[ $\mathrm{t}$ ] he class which has means of material production at its disposal, has the control at the same time over the means of intellectual production. ${ }^{74}$

Klare argues that the Constitution expresses a particular solicitude for and commitment to assist and protect especially vulnerable groups in the form of participatory governance: Put differently, the Constitution envisages inclusive, participatory, accountable, transparent and decentralised institutions of governance and contemplates that government will actively promote and deepen a culture of democracy. ${ }^{75}$ Similarly, legal pluralism challenges the centrality of state law. ${ }^{76}$ However, despite the abovementioned constitutional commitments, the government and/ or organs of state continuously endorse epistemicide and underestimate the epistemic value of generating knowledge from the social location of unexpected places or marginalised groups. This is exhibited by the rise of 'Fallism' where citizens (mostly, those that form the base) are subjected to violence when they 'voice' their concerns or attempt to contribute to the epistemology as a result of them being in the periphery in terms of class system. Thus, there is minimal accountability, if any, on the part of the state as this reaction, i.e. shootings towards the fallist movements' activists, has been normalised by the superstructure, coupled by its policies that maintain exclusive institutions of public knowledge by way of diverting the struggle of the poor to courts because it is known that this is where the poor are weak - for as long as the legal system is commodified, it will be strongly biased towards the rich and powerful because they can afford the fees required by the top law firms in the country for a better legal representation. ${ }^{77}$ In essence, the shootings that take place at the fallist movements symbolise the destruction of knowledge from the marginalised in that they are denied the opportunity to contribute to the public epistemology and therefore shape the policies that govern them in a manner that will, at least, address their social concerns. Judge Weinkove's statement that: 'She doesn't know what the budget of the City Council is; She doesn't know this stuff. She is a kitchen assistant' is an example of how classism has been utilised to resist the marginalised form contributing to the public epistemology. 


\section{Conclusion}

The demand for epistemic diversity challenges a priori and the individualistic nature of traditional epistemology and prepares citizens for their role in supporting policies that maintain credible inclusive institutions of public knowledge. ${ }^{78}$ Epistemic violence persists in 'post'-apartheid South Africa, where, for example, the higher education system, rooted in apartheid and colonial exploitation and racism, has obliterated nearly all the linkages that black students may have with the prescribed texts, propagated narratives, debates and learning on the one side and their history, lived experiences and dreams on the other side. ${ }^{79}$ Through education, they are expected to learn to 'speak well' and gain skills and Eurocentric knowledge that will allow them to enter the marketplace but not allow them to fundamentally change the status quo in society and the economy. ${ }^{80}$ In this essay, I demonstrated how critical legal theories could offer critical interventions into the development of a critical jurisprudence and reflected on the fundamental paradox of 'post'-apartheid South Africa. I used the RMFM to show why we need to, and how we can, reconsider and unearth suppressed knowledges that shaped, and are shaping, South Africa. I also established that the theoretical legal understanding need not be seen oxymoronic but as one that perpetuates the jurisprudence of generosity. ${ }^{81}$

78 Robertson (n 17) 299.

79 International $360^{\circ}$ (n 33).

80 International $360^{\circ}$ (n 33).

81 P Williams 'The alchemy of race and rights' (1991) Harvard University Press 8. 